\title{
Screening of Some Plants Used in the Brazilian Folk Medicine for the Treatment of Infectious Diseases
}

\author{
Fabíola Barbiéri Holetz, Greisiele Lorena Pessini, Neviton Rogério Sanches, Diógenes \\ Aparício Garcia Cortez*, Celso Vataru Nakamura**, Benedito Prado Dias Filho**/+
} Programa de Pós-graduação em Ciências Farmacêuticas *Departamento de Farmácia e Farmacologia **Departamento de Análises
Clínicas, Universidade Estadual de Maringá, Av. Colombo 5790, 87020-900 Maringá, PR Brasil

Extracts of 13 Brazilian medicinal plants were screened for their antimicrobial activity against bacteria and yeasts. Of these, 10 plant extracts showed varied levels of antibacterial activity. Piper regnellii presented a good activity against Staphylococus aureus and Bacillus subtilis, a moderate activity on Pseudomonas aeruginosa, and a weak activity against Escherichia coli. Punica granatum showed good activity on $\mathrm{S}$. aureus and was inactive against the other standard strains. Eugenia uniflora presented moderate activity on both $\mathrm{S}$. aureus and $\mathrm{E}$. coli. Psidium guajava, Tanacetum vulgare, Arctium lappa, Mikania glomerata, Sambucus canadensis, Plantago major and Erythrina speciosa presented some degree of antibacterial activity. Spilanthes acmella, Lippia alba, and Achillea millefolium were considered inactive. Five of the plant extracts presented compounds with Rf values similar to the antibacterial compounds visible on bioautogram. Of these, three plants belong to the Asteraceae family. This may mean that the same compounds are responsible for the antibacterial activity in these plants. Anticandidal activity was detected in nine plant extracts (P. guajava, E. uniflora, P. granatum, A. lappa, T. vulgare, M. glomerata, L. alba, P. regnellii, and P. major). The results might explain the ethnobotanical use of the studied species for the treatment of various infectious diseases.

Key words: medicinal plants - antibacterial activity - anticandidal activity - bioautography

The use of medicinal plants in the world, and especially in South America, contributes significantly to primary health care. Many plants are used in Brazil in the form of crude extracts, infusions or plasters to treat common infections without any scientific evidence of efficacy. Pharmacological studies done with essential oils from 15 species of aromatic plants obtained in Northeast of Brazil have shown activity coherent with the use of these plants in folk medicine. These studies have dealt with the effect of these oils on muscle contraction and with their antispasmodic, analgesic, anti-inflammatory, anticonvulsant and antibacterial activity (Leal-Cardoso $\&$ Fonteles 1999).

Recently, Nakamura et al. (1999) reported the antibacterial activity of both essential oil and purified active compound of Ocimum gratissimum, traditionally used in Brazilian folk medicine to treat different diseases, e. g. upper respiratory tract infections, diarrhoea, skin diseases, pneumonia, and also as a treatment for cough, fever and conjunctivitis. The compound that showed antibacterial activity for gram-positive and gram-negative bacteria in the essential oil was identified as eugenol by spectral data.

This study was supported by grants from the Conselho Nacional de Desenvolvimento Científico e Tecnológico, CNPq, Capacitação de Aperfeiçoamento de Pessoal de Nível Superior, Capes, and Programa de Pós-graduação em Ciências Farmacêuticas da Universidade Estadual de Maringá.

${ }^{+}$Corresponding author. Fax: +55-44-261.4490. E-mail: bpdfilho@uem.br

Received 1 October 2001

Accepted 6 September 2002
More recently, Alves et al. (2000) had screened 60 medicinal plant species from the Brazilian savanna for molluscicidal activity, toxicity to brine shrimp, antifungal activity and antibacterial activity. In this study, 42 species afforded extracts that showed some degree of activity in one or more of these bioassays.

Plants which have been used as medicines over hundreds of years, constitute an obvious choice for study. It is interesting to determine whether their traditional uses are supported by actual pharmacological effects or merely based on folklore. In the present study, we chose 13 plants currently used in the folk medicine in our region. All of them have been used in the treatment of infectious disease, so that the in vitro antimicrobial activity was investigated.

\section{MATERIALS AND METHODS}

Plant collection - The plants were collected in March 2001, in Maringá, PR, Brazil. The plants were identified by the same researchers that accomplished the collection, deposited and authenticated at Herbarium of State University of Maringá, Maringá, PR, Brazil (Table I).

Preparation of extracts - The plant parts selected were ground, submitted to a maceration process with ethanolwater (90-10\%) for $48 \mathrm{~h}$ at $25^{\circ} \mathrm{C}$ and protected from sunlight. The hydroalcoholic extract obtained was evaporated under vacuum, lyophilised and the residue directly assayed against the microorganisms presented below.

Microorganisms used and growth conditions - The test organisms included the bacteria Escherichia coli ATCC 25922, Pseudomonas aeruginosa ATCC 15442, Bacillus subtilis ATCC 6623, and Staphylococcus aureus ATCC 25923. The yeasts Candida albicans, $C$. krusei, $C$. parapsilosis, and C. tropicalis were obtained from local 
clinical microbiology laboratories. The bacteria were grown in nutrient broth (Difco Laboratories, Detroit, $\mathrm{MI}$ ) at $37^{\circ} \mathrm{C}$ and maintained on nutrient agar slants at $4^{\circ} \mathrm{C}$. The yeasts were grown and maintained on Sabouraud-dextrose agar (Merck SA, São Paulo, Brazil).

Antimicrobial susceptibility testing - The minimum inhibitory concentrations (MICs) of all extracts and reference antibiotics (tetracycline, vancomycin, penicillin, and nistatin; Sigma Chemical Co., St. Louis, MO) were determined by microdilution techniques in MuellerHinton broth (Merck) for bacteria and RPMI-1640 (Sigma Chemical Co.) for fungi (NCCSL 1999, 2000). Each extract ( $2 \mathrm{mg} / \mathrm{ml}$ ) was aseptically mixed with inoculum prepared in the same media at a density adjusted to the tube 0.5 of McFarland' scale ( $10^{6}$ yeasts or $10^{8}$ bacterial cells), and diluted 1:10 for the broth microdilution procedure. Microtiter trays were incubated at $37^{\circ} \mathrm{C}$ and the MICs were recorded after $24 \mathrm{~h}$ of incubation. Two susceptibility endpoints were recorded for each isolated. The MIC was defined as the lowest concentration of compounds that produced an $80 \%$ reduction in visible growth compared with control. MBCs were defined as the lowest concentration yielding negative subcultures or only one colony.

Thin layer chromatography - Kieselgel $\mathrm{GF}_{254}$ plates, $20 \times 20 \mathrm{~cm}, 1 \mathrm{~mm}$ thick, were used. Plant extracts were applied and the chromatogram developed using $\mathrm{CHCl}_{3}$ / $\mathrm{MeOH} / \mathrm{H}_{2} \mathrm{O}(65: 35: 5)$ as solvent. TLC plates were run in duplicate and one set was used as the reference chromatogram. Spots and bands were visualized by UV irra-

TABLE I

Traditional use of species selected for antimicrobial investigation

\begin{tabular}{|c|c|c|c|}
\hline $\begin{array}{l}\text { Species (family) (Herbarium } \\
\text { number according to collector) }\end{array}$ & Local name & Part tested & Popular use \\
\hline $\begin{array}{l}\text { Arctium lappa Willd (Asteraceae) } \\
(8426)\end{array}$ & $\begin{array}{l}\text { Bardana, Bardana-maior, } \\
\text { Orelha-de-gigante }\end{array}$ & Leaf & $\begin{array}{l}\text { Leaves and stem are used to treat abscess, skin } \\
\text { injuries, insect bites, mycosis, and genital } \\
\text { affections (1) }\end{array}$ \\
\hline $\begin{array}{l}\text { Tanacetum vulgare } \mathrm{L} . \\
\text { (Asteraceae) (8425) }\end{array}$ & $\begin{array}{l}\text { Tanaceto, Erva dos } \\
\text { vermes }\end{array}$ & Leaf & $\begin{array}{l}\text { Leaves, flowers, and seeds are recommended as } \\
\text { anti-inflammatory and helminth infections (2) }\end{array}$ \\
\hline $\begin{array}{l}\text { Erythrina speciosa Andrews } \\
\text { (Leguminosae Papilionidae) ( } 8416)\end{array}$ & Mulungu & Stem & $\begin{array}{l}\text { The traditional usage indicates that Erythrina } \\
\text { species could have analgesic, anti-inflammatory } \\
\text { and antibacterial activity ( } 3 \text { ) }\end{array}$ \\
\hline $\begin{array}{l}\text { Psidium guajava L (Myrtaceae) } \\
\text { (8423) }\end{array}$ & Goiabeira & Leaf & $\begin{array}{l}\text { Leaf, root, and bark extracts are used for } \\
\text { treatment of diarrhoea, leukorrhea, cholera, } \\
\text { external ulcers, and skin diseases ( } 4 \text { ) }\end{array}$ \\
\hline $\begin{array}{l}\text { Mikania glomerata Spreng } \\
\text { (Asteraceae) }(8420)\end{array}$ & Guaco & Leaf & $\begin{array}{l}\text { Leaves infusion used as antiseptic, anti- } \\
\text { inflammatory, and antibacterial }(4,5,6)\end{array}$ \\
\hline $\begin{array}{l}\text { Spilanthes acmella Mart. } \\
\text { (Asteraceae) (8418) }\end{array}$ & Agrião-do-Brasil, Jambu & Leaf & $\begin{array}{l}\text { A decoction or infusion of the leaves and } \\
\text { flowers is recommended for stammering, } \\
\text { toothache, stomatitis and throat complaints (4) }\end{array}$ \\
\hline $\begin{array}{l}\text { Lippia alba (Mill.) N.E.Br. } \\
\text { (Verbenaceae) (8421) }\end{array}$ & $\begin{array}{l}\text { Erva-cidreira, Erva-cidreira- } \\
\text { brasileira, Alecrim-do- } \\
\text { campo, Chá-da-febre }\end{array}$ & Leaf & $\begin{array}{l}\text { Its leaves are employed as an fusion or decoction } \\
\text { to treat gastrointestinal disorders, dysentery, } \\
\text { colds and cough, as well as febrifuge (4) }\end{array}$ \\
\hline $\begin{array}{l}\text { Achillea millefolium L. Asteraceae } \\
\text { (Asteraceae) }(8424)\end{array}$ & $\begin{array}{l}\text { Mil-folhas, } \\
\text { Erva-de- cortadura }\end{array}$ & Leaf & $\begin{array}{l}\text { Flowers and leaves are used to treat wounds, } \\
\text { ulcers, diarrhoea, skin injuries, and } \\
\text { gastrointestinal disorders }(3,4)\end{array}$ \\
\hline $\begin{array}{l}\text { Piper regnellii Miq. } \\
\text { (Piperaceae) ( } 8392 \text { ) }\end{array}$ & Pariparoba, Capeva & Leaf & $\begin{array}{l}\text { Leaf and root are used in the form of crude } \\
\text { extracts, infusions or plasters to treat common } \\
\text { infections (1) }\end{array}$ \\
\hline $\begin{array}{l}\text { Eugenia uniflora } \mathrm{L} \\
\text { (Myrtaceae) (8419) }\end{array}$ & Pitanga & Leaf & $\begin{array}{l}\text { Leaves are used for treatment of throat } \\
\text { complaints (4) }\end{array}$ \\
\hline $\begin{array}{l}\text { Punica granatum L (Punicaceae) } \\
\text { (8417) }\end{array}$ & Romã & Fruit & $\begin{array}{l}\text { Fruit is used against aphtha, diarrhoea, intestinal } \\
\text { parasites }(4,6)\end{array}$ \\
\hline $\begin{array}{l}\text { Sambucus canadensis L. } \\
\text { (Caprifoliaceae) (8422) }\end{array}$ & Sabugueiro & Leaf & $\begin{array}{l}\text { Leaf, flower, and fruit extracts of parts of these } \\
\text { plants have been used for respiratory and } \\
\text { pulmonary disorders (cold, coughs, etc.) }(4,6)\end{array}$ \\
\hline $\begin{array}{l}\text { Plantago major } \mathrm{L} \text {. } \\
\text { (Plantaginaceae) }(8427)\end{array}$ & $\begin{array}{l}\text { Tanchagem, } \\
\text { Erva-de-orelha }\end{array}$ & Leaf & $\begin{array}{l}\text { Leaves and seeds are used as antiseptic, anti- } \\
\text { inflammatory, and antibacterial }(4,6,8)\end{array}$ \\
\hline
\end{tabular}


diation (254 and $366 \mathrm{~nm}$ ) and $\mathrm{H}_{2} \mathrm{SO}_{4}$ spray reagent. The other set was used for bioautography.

Bioautography - Chromatogram developed as described above was placed in plate square with cover and a inoculum of $S$. aureus containing $10^{6} \mathrm{CFU} / \mathrm{ml}$ in molten Mueller-Hinton agar was distributed over the plates. After solidification of the medium, the TLC plate was incubated overnight at $37^{\circ} \mathrm{C}$. Subsequently bioautogram was sprayed with an aqueous solution of 2,3,5-triphenyltetrazolium chloride (TTC) and incubated at $37^{\circ} \mathrm{C}$ for $4 \mathrm{~h}$. Inhibition zones indicated the presence of active compounds.

\section{RESULTS AND DISCUSSION}

The ethnobotanical screening tests of hydroalcoholic extracts of 13 plants against both gram-positive and gramnegative bacteria and yeasts by using the microdilution technique are given in Table II. It was considered that if the extracts displayed an MIC less than $100 \mu \mathrm{g} / \mathrm{ml}$, the antimicrobial activity was good; from 100 to $500 \mu \mathrm{g} / \mathrm{ml}$ the antimicrobial activity was moderate; from 500 to $1000 \mu \mathrm{g} /$ $\mathrm{ml}$ the antimicrobial activity was weak; over $1000 \mu \mathrm{g} / \mathrm{ml}$ the extract was considered inactive. Piper regnellii presented a good activity against the gram-positive bacteria S. aureus and B. subtilis with MIC of 7.8 and $15.6 \mu \mathrm{g} / \mathrm{ml}$, respectively, a moderated activity on the gram-negative P. aeruginosa with MIC of $250 \mu \mathrm{g} / \mathrm{ml}$, and a weak activity against the gram-negative $E$. coli with MIC $1000 \mu \mathrm{g} / \mathrm{ml}$. Punica granatum showed good activity on $S$. aureus with MIC of $62.5 \mu \mathrm{g} / \mathrm{ml}$ and was inactive against the other standard strains at concentrations $\geq 1000 \mu \mathrm{g} / \mathrm{ml}$. On the other hand, Psidium guajava afforded extract with moderate activity against gram-positive bacteria and on the gramnegative bacteria E. coli, while the extracts of Arctium lappa, Tanacetum vulgare and Mikania glomerata presented some degree of activity against both gram-positive and gram-negative bacteria. Eugenia uniflora presented moderate activity on both $S$. aureus and E. coli. Sambucus canadensis shown moderate activity against B. subtilis, and Plantago major was weakly active on $S$. aureus. Spilanthes acmella, Lippia alba, and Achillea millefolium were considered inactive. The minimal bactericidal concentrations were within two-twofold dilution of the MICs for these organisms. The most susceptible bacterium was $S$. aureus.

Different results were obtained for the 13 studied species for antifungal activity against the yeasts $C$. albicans, C. krusei, C. parapsilosis, and C. tropicalis. In the antiyeast assay, $P$. guajava extract displayed good activity against all the yeasts tested at concentrations of 15.6 to $125 \mu \mathrm{g} / \mathrm{ml}$. Both E. uniflora and P. granatum afforded extracts with good activity against some yeast, but were inactive on $C$. albicans. The extracts of $L$. alba and $P$. major showed moderate response against $C$. krusei, and a weak activity on C. tropicalis, but did not show any activity against $C$. albicans and $C$. parapsilosis. M. glomerata and $P$. regnellii yielded extracts with moderate activity against $C$. krusei and $C$. tropicalis, while $A$. millefolium extract was weakly active against $C$. krusei. E. speciosa, S. acmella, and S. canadensis were inactive for all the yeasts tested.

To obtain some information on the active components, plant extracts were analyzed by TLC on silica gel. TLC plates were run in duplicate and one set was used as the reference chromatogram, and the other set was assayed for bioautography (Figure). Panel A shows the chromatogram of plant extracts sprayed with Vanillin/Sulphuric acid. Panel B shows the appearance of same chromatogram after treatment with bacterial inoculum, indicating the location of bacterial inhibition zone. Two antibacterial compounds were detected in the origin. These compounds were present in the extracts from E. uniflora (Line 10) and P. granatum (Line 11). P. guajava presented antibacterial compound (s) with $R f$ of 0.68 (Line 4). All other antibacterial compounds presented similar $R f$ values (0.85-0.93), and were detected in the extracts from A. lappa (Line 1), $T$. vulgare (Line 2), E. speciosa (Line 3), M. glomerata (Line 5) and $P$. regnellii (Line 9). In the solvent system used for screening, it forms a streak which can extend over more

TABLE II

Minimal inhibitory concentration (MIC) of 13 Brazilian medicinal plants

\begin{tabular}{|c|c|c|c|c|c|c|c|c|}
\hline \multirow[b]{3}{*}{ Plants } & \multicolumn{7}{|c|}{$\mathrm{MIC}(\mu \mathrm{g} / \mathrm{ml})$} & \\
\hline & \multicolumn{4}{|c|}{ Antibacterial activity } & \multicolumn{4}{|c|}{ Antifungal activity } \\
\hline & $\begin{array}{c}\text { Staphylococus } \\
\text { aureus }\end{array}$ & $\begin{array}{c}\text { Bacillus } \\
\text { subtilis }\end{array}$ & $\begin{array}{c}\text { Escherichia } \\
\text { coli }\end{array}$ & $\begin{array}{c}\text { Pseudomonas } \\
\text { aeruginosa }\end{array}$ & $\begin{array}{l}\text { Candida } \\
\text { albicans }\end{array}$ & C. krusei & C. parapsilosis & C. tropicalis \\
\hline Arctium lappa & 500 & 500 & 500 & 500 & $>1000$ & $>1000$ & $>1000$ & $>1000$ \\
\hline Tanacetum vulgare & $>1000$ & 500 & 500 & 500 & $>1000$ & 500 & $>1000$ & 500 \\
\hline Erythrina speciosa & 500 & 250 & $>1000$ & $>1000$ & $>1000$ & $>1000$ & $>1000$ & $>1000$ \\
\hline Psidium guajava & 250 & 500 & 500 & $>1000$ & 125 & 15.6 & 62.5 & 15.6 \\
\hline Mikania glomerata & 500 & 250 & 500 & $>1000$ & $>1000$ & 500 & $>1000$ & 500 \\
\hline Spilanthes acmella & $>1000$ & $>1000$ & $>1000$ & $>1000$ & $>1000$ & $>1000$ & $>1000$ & $>1000$ \\
\hline Lippia alba & $>1000$ & $>1000$ & $>1000$ & $>1000$ & $>1000$ & 125 & $>1000$ & 1000 \\
\hline Achillea millefolium & $>1000$ & $>1000$ & $>1000$ & $>1000$ & $>1000$ & 1000 & $>1000$ & $>1000$ \\
\hline Piper regnellii & 7.8 & 15.6 & 1000 & 250 & $>1000$ & 125 & $>1000$ & 500 \\
\hline Eugenia uniflora & 250 & $>1000$ & 500 & $>1000$ & $>1000$ & 31.2 & 125 & 31.2 \\
\hline Punica granatum & 62.5 & $>1000$ & $>1000$ & $>1000$ & $>1000$ & 15.6 & 12.5 & 15.6 \\
\hline Sanbucus canadensis & $>1000$ & 250 & $>1000$ & $>1000$ & $>1000$ & $>1000$ & $>1000$ & $>1000$ \\
\hline Plantago major & 1000 & $>1000$ & $>1000$ & $>1000$ & $>1000$ & 125 & $>1000$ & 1000 \\
\hline
\end{tabular}


than one $R f$ unit, which may overlap with other active compounds in the extracts. Also, due to clustering of bioautography zones detected in the origin, it was difficult to distinguish individual compounds. Use of additional, more polar solvent system to develop TLC plates in future work on individual plants will allow better separation on these zones. In the Mirtaceae family there is a large variety of active principles against microorganisms including essential oils, flavonoids, (Slowing et al. 1994, Lis-Balchin et al. 2000, Hernández et al. 2000) and tannins (Scalbert 1991, Djipa et al. 2000). The presence of flavonoids and tannins in Punicaceae family can be responsible by antimicrobial activity (Sahar et al. 1997). Since the antimicrobial activity in species of the Piperaceae family has been found with the amides, essential oil, lignans, phenylpropanoids, alkaloids, neolignans and chromene (Masuda et al. 1991, Benevides et al. 1999, Costantin et al. 2001, Dorman \& Deans 2000), its is possible that these compounds could be responsible by the antimicrobial properties reported here.

Under the conditions employed here, all test samples have more potent inhibitory effects on gram-positive bacteria in comparison to gram-negative bacteria. According to the TLC separation, five plant extracts yielded components with $R f$ values similar to the antibacterial compounds visible on bioautograms. In addition, many of these inhibition zones were associated with dark blue spots which had been detected under UV radiation (data not shown). Of these, three plants belong to the Asteraceae family. This may mean that the same compounds are responsible for the antibacterial activity in these plants.

In the present study hydroalcoholic extracts of some Brazilian medicinal plants were tested against bacteria and yeasts. Ten out of 13 plant extracts from eight families displayed some degree of antibacterial activity, in particular against the gram-positive bacteria $S$. aureus and $B$.

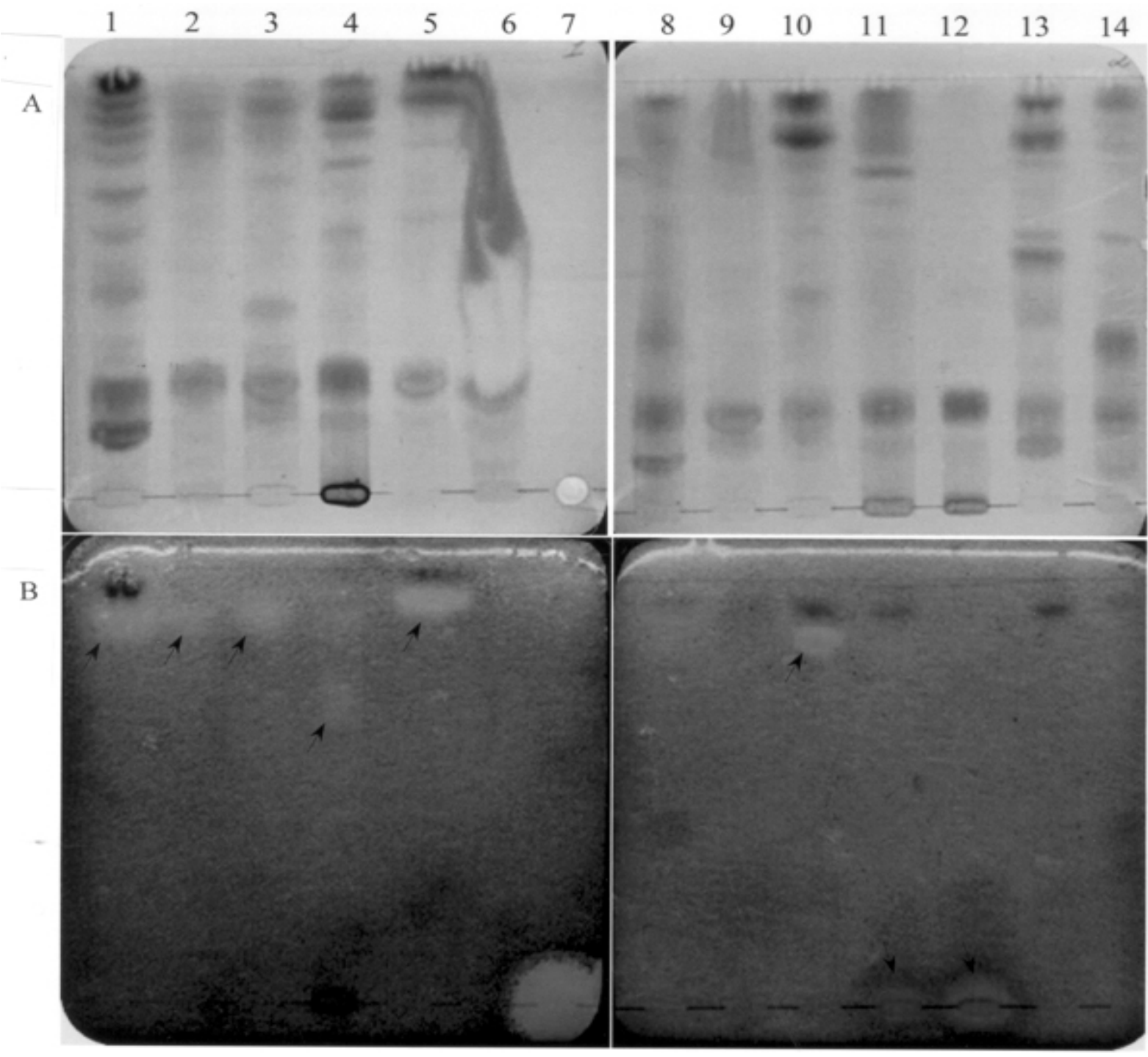

Thin layer chromatography plates of 13 Brazilian medicinal plants were run in duplicate and one set was visualized by Vanillin/Sulfuric acid spray reagent (A). The other set was used for bioautography with Staphylococcus aureus (B). 1: Arctium lappa; 2: Tanacetum vulgare; 3: Erythrina speciosa; 4: Psidium guajava; 5: Mikania glomerata; 6: Spilanthes acmella; The reference compound was vancomycin; 7: Lippia alba; 8: Achillea millefolium; 9: Piper regnellii; 10: Eugenia uniflora; 11: Punica granatum; 12: Sambucus canadensis; 13: Plantago major. Arrows indicate antibacterial activity. 
subtilis, representing more than $77 \%$ of the screened extracts. This is to be expected because the outer membrane of gram-negative bacteria is known to present barrier to penetration of numerous antibiotic molecules, and the periplasmic space contains enzymes, which are able of breaking down foreign molecules introduced from outside (Duffy \& Power 2001). It was interesting that the extracts of $P$. regnellii showed response on both grampositive and gram-negative bacteria and yeasts. In spite of $P$. guajava exhibited good activity against all the yeasts and a moderate activity against gram-positive bacteria, the inhibitory activity against gram-negative bacteria displayed by the extract was low.

Although this study investigated the in vitro antimicrobial activity, the results substantiate the ethnobotanical use of the 13 studied species for the treatment of various bacteria-related diseases. However, in vivo data may be helpful in determining the potential usefulness of these plants for treatment of infectious diseases. In terms of conservation, the results show that leaf material is useful for antimicrobial uses, and it could be used without any detrimental effect on the plant.

\section{ACKNOWLEDGMENTS}

To Marinete Martinez for help in the experiments.

\section{REFERENCES}

Alves TMA, Silva AF, Brandão M, Grandi TSM, Smânia EF, Smânia Jr A, Zani CL 2000. Biological screening of Brazilian medicinal plants. Mem Inst Oswaldo Cruz 95: 367-373.

Alzugaray D 1983. Plantas que Curam, Três Livros e Fascículo, São Paulo, vol. I 140 pp.; vol. III 126 pp.

Benevides PJC, Sartorelli, P, Kato MJ 1999. Phenylpropanoids and neolignans from Piper regnellii. Phytochemistry 52: 339343.

Biazzi ES 1996. Saúde pelas Plantas, Casa Publicadora Brasileira, Tatuí, São Paulo, 176 pp.

Corrêa MP 1984. Dicionário de Plantas Úteis do Brasil, Ministério da Agricultura, Instituto Brasileiro de Desenvolvimento Florestal, Brasilia, DF, vol. I 747 pp.; vol. II 777 pp.; vol. IV 765 pp.; vol. V 687 pp.

Costantin MB, Sartorelli P, Limberger R, Henriques AT, Steppe M, Ferreira MJ, Ohara MT, Emerenciano VP, Kato MJ 2001. Essential oils from Piper cernuum and Piper regnellii: antimicrobial activities and analysis by GC/MS and 13CNMR. Planta Med 67: 771-773.

Cruz CN 1979. Dicionário de Plantas Úteis do Brazil, Civilização Brasileira, Rio de Janeiro, 599 pp.

Djipa CD, Delmée M, Quetin-Leclercq J 2000. Antimicrobial activity of bark extracts of Syzygium jambos (L.) Alston (Myrtaceae). J Ethnopharmacol 71: 307-313.

Dorman HJ, Deans SG 2000. Antimicrobial agents from plants: antibacterial activity of plant volatile oils. J Appl Microbiol 88: $308-316$.

Duffy CF, Power RF 2001. Antioxidant and antimicrobial properties of some Chinese plants extracts. Int J of Antimicrob Agents 17: 527-529.

Hernández NE, Tereschuk ML, Abdala LR 2000. Antimicrobial activity of flavonoids in medicinal plants from Tafí del Valle (Tucumán, Argentina). J. Ethnopharmacol 73: 317322.

Leal-Cardoso JH, Fonteles MC 1999. Pharmacological effects of essential oils of plants of the northeast of Brazil. An Acad Bras Cienc 71: 207-213.

Lis-Balchin M, Hart SL, Deans SG 2000. Pharmacological and antimicrobial studies on different tea-tree oils (Melaleuca alternifolia, Leptospermum scoparium or Manuka and Kunzea ericoides or Kanuka), originating in Australia and New Zealand. Phytother Res 14: 623-629.

Masuda T, Inazumi A, Yamada Y, Padolina WG, Kikuzaki H, Nakatani N 1991. Antimicrobial phenylpropanoids from Piper sarmentosum. Phytochemistry 30: 3227-3228.

Nakamura CV, Ueda-Nakamura T, Bando E, Melo AFN, Cortez DAG, Dias Filho BP 1999. Antibacterial activity of Ocimum gratissimum L essential oil. Mem Inst Oswaldo Cruz 94: 675-678.

NCCLS-National Committee for Clinical Laboratory Standards 2000. Methods for Dilution Antimicrobial Susceptibility Tests for Bacteria that Grow Aerobically, Wayne, Pa.

NCCLS-National Committee for Clinical Laboratory Standards 1999. Methods for Determining Bactericidal Activity of Antimicrobial Agents, Wayne, Pa.

Neto GG 1987. Plantas Utilizadas na Medicina Popular do Estado do Mato Grosso, CNPq Assessoria Editoral, Brasília, $58 \mathrm{pp}$.

Oliveira F, Kisue G 1989. Fudamentos de Farmaco-botânica, Atheneu, Rio de Janeiro, $412 \mathrm{pp}$.

Sahar AM, Hussein HHB, Irmgard M, Mahmoud AMN 1997. Tannins from the leaves of Punica granatum. Phytochemistry 45: 819-823.

Scalbert A 1991. Antimicrobial properties of tannins. Phytochemistry 30: 3875-3883.

Silva I, Sant'Ana DMG 1995. Noções sobre o Organismo Humano e a Utilização de Plantas Medicinais, AssoesteEditora Educativa, Cascavel, Paraná, 203 pp.

Slowing K, Söllhuber M, Carretero E, Villar A 1994. Flavonoid glycosides from Eugenia jambos. Phytochemistry 37: 255258.

Zatta IM 1998. A Farmácia da Natureza, Paulinas, São Paulo, $143 \mathrm{pp}$. 